E3S Web of Conferences 1, 34001 (2013)

DOI: $10.1051 / \mathrm{e} 3$ sconf/20130134001

(C) Owned by the authors, published by EDP Sciences, 2013

\title{
Metal Accumulation, Blood ס-Aminolevulinic Acid Dehydratase Activity and Micronucleated Erythrocytes of Feral pigeons (Columba Livia) Living Near Former Lead-Zinc Smelter "Trepça” - Kosovo
}

\author{
I. R. Elezaj ${ }^{1}$, I. Q. Selimi ${ }^{1}$, K. Rr. Letaj ${ }^{1}$, L. B. Millaku ${ }^{1}$ and L. Sefaja ${ }^{2}$ \\ 1Department of Biology, University of Prishtina, Republic of Kosovo isaelezaj@hotmail.com, qselimi@yahoo.com, \\ kletaj2003@yahoo.com, lulzimmillaku@hotmail.com \\ ${ }^{2}$ National Institute of Public Health, Medical Faculty, University of Prishtina, Republic of Kosovo, \\ lirush_516@hotmail.com
}

\begin{abstract}
The concentration of lead in blood and tibia $(\mathrm{Pb})$, zinc $(\mathrm{Zn})$ and cupper $(\mathrm{Cu})$ in tibia, blood $\delta$ aminolevulinic acid dehydratase (ALA-D; EC: 4.2.1.24) activity, hematocrit value (Hct) and micronuclei frequency $(\mathrm{MN})$ of peripheral erythrocytes have been determinated in three different populations of feral pigeons (Columba livia; forma urbana and forma domestica), collected in Mitrovica town (situated close to smelter "Trepça", down closed in 2000 year ) and in rural area (Koshare willage ). The blood lead level in feral pigeons from Mitrovica (forma urbana) was 3 times higher $(149.6 ; 50.5 \mu \mathrm{g} \%$ ) in comparison with that in feral pigeons from Mitrovica (forma domestica) and 27.7 times higher (5.4 $\mu \mathrm{g} \%$ in comparison with pigeons from rural area. The $\mathrm{Pb}$ concentration of tibia of feral pigeons (froma urbana and forma domestica), from Mitrovica town was significantly higher $(\mathrm{P}<0.001)$ in comparison with control. The concentration of $\mathrm{Zn}$ in tibia of feral pigeons from Mitrovica town (forma urbana), was significantly higher $(\mathrm{P}<0.006)$ in comparison with control. The blood ALA-D activity of feral pigeons from Mitrovica town (forma urbana and froma domestica), was significantly inhibited in comparison with control. The blood ALA-D activity of feral pigeons -forma urbana from Mitrovica town was significantly inhibited $(\mathrm{P}<0.001)$ in comparison with the blood ALA-D activity of feral pigeons-forma domestica from Mitrovica town. The erythrocyte MN frequency of feral pigeons from Mitrovica was significantly higher $(\mathrm{P}<0.001)$ in comparison with controls. The smelter "Trepça" ten year after closed down pose a threat to the local environment, biota and people's health.
\end{abstract}

Key words: Columba livia; metals; ALA-D; micronuclei; hematocrit

\section{Introduction}

Pollution of ecosystems by man-made chemicals still is increasing in the highly industrialized countries as well as in the Third world. Therefore pollution assessment by monitoring is of paramount importance. Species useful for this purpose must be representative for the area under investigation, sedentary accumulators of environmental pollution (Drasch et al., 1987), e.g. by heavy metals, and useful for long term storage also from the view of retrospective analysis within Environmental specimen Banking. From this view it appears that particular approaches of bio monitoring may become a means to fulfil these requirements since animals with known habits are span or at least an important part of it. The enzyme $\delta$ aminolevulinic acid dehydratase (ALA-D; E.C. 4.2.1.24), catalysis the second step of haeme biosynthetic pathway and is required to maintain the haemoglobin and cytochrome content in red blood cells. ALA-D is not only found in bone marrow cells, the major site of haeme synthesis, but also in circulating erythrocytes and other tissues. The level of ALA-D inhibition in erythrocytes has been widely accepted as a standard bioassay to detect acute and chronic lead exposure in humans and birds ( Elezaj et al., 2008; Selimi et al., 2008). The value of this parameter as an indicator for environmental lead pollution has been reported in doves (Hutton M., 1983; Elezaj et al., 2008 ; Selimi et al., 2008). On the other hand common environmental pollutants, together with nuclear radiation, are recognized as genotoxic (Ilyinskikh et al., 1997). Several heavy metals were found to have harmful effects on DNA (Warchalowska-Sliwa, 2005). Elevated germ-line mutations have been documented in birds in industrial areas (Yauk et al., 2000). There is, however, very little information on pollution - related genetic effects in wild bird populations living in smelting 
areas. On the other hand, the ability of feral pigeons to accumulate high metal concentrations is considered to be desirable characteristic in an indicator organism and this would facilitate periodic monitoring of lead and other metals in urban and industrial environments (Hutton and Goodman 1980; Elezaj et al., 2008). The present study examined the concentration of $\mathrm{Pb}, \mathrm{Zn}$ and $\mathrm{Cu}$ in tibia, lead level in blood $(\mathrm{BPb})$, blood ALA-D activity, peripheral erythrocyte micronuclei frequency $(\mathrm{MN})$ and hematocrit value of two feral pigeon (Columba livia), populations, residing and living in different conditions in Mitrovica town (urban and smelting polluted area) and in feral pigeon population living in rural area. Since in urban areas this species is sedentary, forming discrete flocks which remain faithful to specific feeding and roosting areas, a relatively small sample of birds is expected to reflect any variation in metal exposure at a local level. Since the smelter "Trepça" was closed down in August, 2000 year we used to examine the feral pigeons (Columba livia - forma urbana) and feral pigeons (Columba livia-forma domestica), in order to evaluate the effect of pollution in a new conditions of Mitrovica environments pollution with heavy metals.

\section{Material and Methods}

Specimens of feral pigeons (Columba livia- forma urbana; 10 birds, males and females and Columba livia forma domestica ; 10 birds males and females), were collected from Mitrovica town (situated in the vicinity of lead and zinc smelter "Trepça" contaminated area) and in village Koshare (10 birds- rural area) in 2010 year. The vicinity of lead and zinc smelter Trepaca" located close to the town of Mitrovica, is extremely polluted with heavy metals, sulphur dioxide and there airborne pollutants. The proximity of Mitrovica to the smelter has resulted in it becoming one of the most polluted areas, not only in Republic of Kosovo but also in the whole Europe.The degree of pollution in this area can be ilustrated by some data of Popovac (Popovac et al., 1981), who found that the amount of lead dust emitted by daily from the "Trepça" smelter in 1979 was in order of 5-6 tones. The concentration of lead in air in the town of Mitrovica during the same period was $20-30 \mu \mathrm{g} / \mathrm{m} 3$. The atmosphere concentrations of cadmium, zinc and sulphur dioxide were also elevated. Until it was closed down on August 14, 2000 year by the United Nations Militray Forces, the "Trepça" smelter in Mitrovica, northen of Republic of Kosovo, leched out lead- tained pollution that was identified in the late 1980 s as a likely cause of measurably reduced intelligence among children in this area. The smelter's closure was a breath of fresh air for local population, as direct emissions of lead particles into atmosphere have beeen prevented, at least ten years from now. But the contamination left behind by years of operation of the "Trepça" smelter pose a serious threat to the local environment and people's health. Recently (Shehu et al., 2011) in a soil of surrounding area of Mitrovica showed very higher concentrations of $\mathrm{Pb}$ ( $23120.0 \mathrm{ppm}), \mathrm{Zn}$ ( $46160 \mathrm{ppm}), \mathrm{Cu}$ ( 3688.0) and $\mathrm{Cd}$ ( $313.0 \mathrm{ppm}$;). In laboratory, blood samples were collected in heparinised tubes by puncturing the alvar vein in the region of the carpal vein joint, after first removing feathers in the area and throughly cleaning the skin. Birds were then killed by cervical dislocation and the tibia excised, precautions being taken to prevent metal contamination. Erythrocyte ALA-D activity was measured according to the CEC standardized method (Berlin and Schaller, 1974). A drop of peripheral blood was obtained from each bird, and it was smeared on two pre-cleaned and pre- coded microscopic slides. The smears were air- dried, fixed in absolute ethanol for 10 minutes and stained with giemsa. The munber of micronucleated erythrocytes were determinated in 2000 blood perihperal erythrocytes using an OLYMPUS microscope under oil-mimmersion objective $(100 \mathrm{x})$. The hematocrit was determined in heparinized capillary tubes, centrifuged for $8 \mathrm{~min}$ at $10.000 \mathrm{rpm}$ (Haemofuge, Heraus). All tibia bone were dried at thermostat at 105 0C for $48 \mathrm{~h}$ and dry ashing as described by Blanusa (Blanusa and Breshki, 1981). Tissue concentration of $\mathrm{Pb}$, $\mathrm{Zn}$ and $\mathrm{Cu}$ was measured by flame atomic absorption spectrophotometry (UNICAM 29).

\section{Results and Discussion}

Lead concentration in tibia of feral pigeons from Mitrovica town (forma urbana and forma domestica) was significantly higher in comparison with controls (Table 1). The $\mathrm{Pb}$ concentration in tibia of feral pigeons from Mitrovica -forma urbana was 2.8 times higher in comparison with $\mathrm{Pb}$ concentration in tibia of feral pigeons from Mmitrovica - forma domestica and 68.8 times higher in comparison with controls. Lead concentration in tibia of feral pigeons from Mitrovica forma domestica was 24.4 times higher in comparison with controls. Zinc concentration in tibia of feral pigeons from Mitrovica- forma urbana was 2.2 times higher in comparison with $\mathrm{Zn}$ concentration in tibia of feral pigeons from Mitrovica-forma urbana and 2.7 times higher in comparison with controls. The concentration of $\mathrm{Cu}$ in tibia of feral pigeons from control area was moderately higher in comparison with concentration in tibia of feral pigeons from Mitrovica - froma urbana and doemstica. Lead level in blood of feral pigeons from Mitrovica - forma urbana was 3 times higher in comparison with blood lead level in feral pigeons from Mitrovica - forma domestica and 27.7 times higher in comparison with controls, while the lead level in blood of feral pigeons from Mitrovica -forma domstica was 9.3 times higher in comparison with lead concentration in blood of feral pigeons from control.

The blood ALAD activity of Feral pigeons from Mitrovica -forma urbana and domestica was significantly inhibited in comparison with control $(\mathrm{P}<0.001)$. The blood ALAD activity in feral pigeons from Mitrovica forma urbana was $94.9 \%$ inhibited in comparison with control while the blood ALA activity of Feral pigeons from Mitrovica-forma domestica was $77.8 \%$ inhibited in comparison with controls. The frequency of micronuclei $(\mathrm{MN})$ in peripheral erythrocytes of feral pigeon's from Mitrovica- forma urbana was significantly higher 
Table 1. The blood ALA-D activity, hematocrit (Hct) micronuclei frequency in erythrocytes, blood lead level (BP b ( $\mu \mathrm{g}$ $\mathrm{g} / \mathrm{dL}$ ), tibia concentration of $\mathrm{Pb}, \mathrm{Zn}$ and $\mathrm{Cu}(\mu \mathrm{g} / \mathrm{g}$ d.w.) in feral pigeons from Mitrocica town (forma urbana and forma doemstica) and from Koshare-rural area.

\begin{tabular}{|c|c|c|c|c|c|c|c|}
\hline Locality & ALA-D & Hct & MN/1000 & $\mathrm{BPb}$ & $\begin{array}{l}\mathrm{Pb} \\
\mathrm{uq} / \mathrm{q} / \mathrm{d} . \mathrm{w}\end{array}$ & $\begin{array}{l}\mathrm{Zn} \\
\mathrm{ug} / \mathrm{q} / \mathrm{d} \cdot \mathrm{w}\end{array}$ & $\begin{array}{l}\mathrm{Cu} \\
\mu \mathrm{q} / \mathrm{q} / \mathrm{d} \cdot \mathrm{w}\end{array}$ \\
\hline Koshare & *** & & & & & & \\
\hline Rural area & $23.4 \pm 3$ & $44 \pm 3$ & $4.0 \pm 3$ & $5.4 \pm 0.6$ & $7.7 \pm 8.1$ & $199 \pm 23$ & $2.9 \pm 2.9$ \\
\hline Mitrovicë & & & $\star \star \star$ & $\star \star \star *$ & $\star \star \star *$ & $\star \star *$ & \\
\hline Urbana & $1.2 \pm 0.9$ & $47 \pm 5$ & $23 \pm 7$ & $149 \pm 60$ & $530 \pm 583$ & $547 \pm 369$ & $1.8 \pm 0.6$ \\
\hline Mitrovicë & & & & $\star \star \star *$ & & ** & \\
\hline Domestica & $5.2 \pm 2.8$ & $49 \pm 1^{\star \star}$ & N.E. & $50 \pm 25$ & $188 \pm 101$ & $240 \pm 127$ & $2.3 \pm 0.7$ \\
\hline
\end{tabular}

Note: Results are expressed as means $\pm \mathrm{SD} ;{ }^{* *} \mathrm{P}<0.001 ;{ }^{* * *} \mathrm{P}<0.001$

$(\mathrm{P}<0.001)$ in comparison with $\mathrm{MN}$ frequency in controls. The results of higher concentrations of lead and zinc in tibia of feral pigeons populations from Mitrovica - forma urbana and domestica are in accordance with results (Elezaj et al. 2008;), who showed wery higher concentration of $\mathrm{Pb}, \mathrm{Cd}, \mathrm{Zn}$ and $\mathrm{Cu}$, in tibia femur, kidney and liver of feral pigeons (Columba livia) from the same area not, only on 2000 year (when "Trepça" smelter was closed down) but in four succesive years. The higher concentrations of $\mathrm{Pb}$ recorded in Pigeons of Mitrovica town-forma urbana $(530 \mu \mathrm{g} / \mathrm{g} \mathrm{d.w.})$ is in accordance with results of Hutton ( 1983) who in feral pigeons from London area redorded wery higher lead concentrations. The higher concentrations of $\mathrm{Pb}$ and $\mathrm{Zn}$ in tibia of feral pigeonn's from Mitrovica-forma urbana not only in comaprison with control but also in comparison with feral pigeons from Mitrovica- forma domestica, after Hutton and Goodman (1980) may be explain by the fact that in much polluted areas dietary ingestion can be important in lead uptake because feed, water and small stones, which serve as gastroliths for feral pigeons, may be highly contaminated with roadside dust and thickly coated with lead. The pronounced inhibition of blood ALA-D activity in feral pigeons from Mitrovica confirms once more the sensitivity of this enzyme to lead. Our results that indicate no relationship between blood ALA-D activity and $\mathrm{BPb}$ in Mitrovica are in agreement with results of Hutton (1983) who determinate that usefulness of blood ALAD activity as bio- analytical index of $\mathrm{BPb}$ is restricted to lightly contaminated individuals. Our results of remarkable inhibition of blood ALA-D activity (77\% and BPb level $50.5 \%$ ) in feral pigeons from Mitrovica are in accordance with results of Finley (Finley et al., 1976), who showed that in humans BPb levels from 50-60 $\mu \mathrm{g} \%$ resulted in a decrease of ALA- D activity by about 75 $\%$.Our results of higher frequency of micronuclei in peripheral erythrocytes of feral pigeons from Mitrovica are in accordance with results of Gomez-Meda (Goemza - Meda et al. 2006), who showed higher frequency of $\mathrm{MN}$ in peripheral erythrocytes of parrots (Aratinga Cannucularis) induced by mitomycin C. These results suggest that evaluation of $\mathrm{MN}$ in routine haematological analysis should be considered to evaluate environmental genotoxic exposure. The smelter "Trepça" ten year after closed down pose a threat to the local environment, biota and people's health.

\section{References}

Berlin A, Schaller K H. European standardized method for the determination of $\delta$-aminolevulinic acid dehydratase activity in blood. Z.Klin.Chem. Biochem. 1974; 12:389-39.

Blanusa M, Breski Dj. Comparison of dry and wet ashing procedures for cadmium and iron determination in biological material by atomic-absorption spectrophotometry. Talanta.1981; 28: 681-684.

Drasch G A, Walser D, Kosters J. The urban pigeon (Columba livia, forma urbana)-a biomonitor for lead burden in the environment. Environmental Monitoring and Assessment. 1987; 9:223-232.

Elezaj IR, Selimi QI, Letaj KRr. The accumulation of $\mathrm{Pb}$, $\delta$-aminolevulinic acid dehydratase, hematocrit and hemoglobin amount of Feral Pigeons (Columba livia) living near lead and zinc smelter "Trepça" in Mitrovica-Kosova, Four year study. Proceedings of 14th International Conference on Heavy Metals in the Environment. 2008: 269-272.

Finley MT, Dieter MP, \&Locke LN. $\delta$ - Aminolevulinic acid dehydratase: Inhibition in ducks dosed with lead shot. Environ. Res. 1976; 12: 243-249.

Gomez -Meda B.C., Zamora-Perez A. L., Aguirre -Luna J., Gonzalez-Rodriguez A M., Ramos-Ibarra L., Torres-Bugarin O., batista-Gonzalez C.M., ZunaGonzalez G.M. Nuclear abnormalities in erythrocytes of parrots (Aratinga canicularis) related to genotoxic damage. Avian Pathology . 2006.; 35 (3): 206-210.

Hutton M, Goodman G T. Metal contamiantion of feral pigeons Columba livia from the London area: Part I: Tissue accumulation of lead, cadmium and zinc. Environ Pollutio. Ser.A. 1980; 22; 207-217.

Hutton M. Metal contamination of feral pigeons Columba livia from the London area: Part II-Biological 
effects of lead exposure. Environ Polut. Ser.A. $1980 ; 22: 281-293$.

Hutton M. The effects of environmental lead exposure and In Vitro zinc on tissue- aminolevulinic acid dehydratase in urban pigeons. Comp. Biochem. Physiol. 1983; 74 C (2): 441-446.

Ilyinskikh N N, Ilyinskikh E N, Ksenz A S, Yurkin A Y. An assessment of frequencies of micronucleated erythrocytes in peripheral blood of pigeons (Columba livia $\mathrm{Gm}$ ) living in the polluted radioactive area around the Siberian Chemical Plant. Environ. Pollut. 1997; 98: 119-122.

Popovac D., Colakovic B., Popovac R., Saljic L., Todorovic P. Environmental pollution in the industrial region of Kosovska Mitrovica and possible effects on human health. Acta. Biol. Med. Exp. 1981; 6: 61- 65 .

Selimi Q I, Elezaj I r, Letaj K Rr. Tissue accumulation of $\mathrm{Pb}, \delta$-aminolevulinic acid dehydratase, hematocrit and hemoglobin amount of Feral Pigeons (Columba livia) living in Prishtina the capital of Kosova ( Four year study). Proceedings of 14th International Conference on Heavy Metals in the Environment. 2008: 257-260.

Shehu I., Demaku S., Arbneshi T., Jusufi S., Shala F., Bobra B. Heavy Metals in Landfill Waste of Trepça, after Flotation Process as Pollutants of Water and Soil. J.Int. environmental Application \& Science. 2011; 6 (3):429-433.

Warchalowska-Sliwa E, Niklinska M, Gorlich A, Michailova P, Pyza E. Heavy metal accumulation, heat chock protein expresion and cytogenetic changes in tetrix tenuicornis (L.) (terigidae, Orthoptera) from polluted areas. Environ . Pollut. 2005; 133: 373-3.

Yauk CL, Fox GA, McCarry BE, Quinn JS. Induced minisatellite germline mutations in herring gullts (Larus argentatus) living near steel mills. Mutat. Res. Fundam. Mol. Mech. Mutagen. 2000; 452:211218. 